\title{
Shape-similar errors in Chinese pure alexia
}

Shi-Lin Yang, MD,* Xiang Han, MD,* and Qiang Dong, MD

Neurology ${ }^{\circledR}$ 2019;92:388-389. doi:10.1212/WNL.0000000000006964
Correspondence

Dr. Dong

dong_qiang@fudan.edu.cn

Figure 1 Examples of shape-similar errors in the oral reading test

$\begin{array}{llllllll}\text { Chardcter shown } & \text { 每 } & \text { 采 } & \text { 京 } & \text { 千 } & \text { 勺 } & \text { 目 } & \text { 木 } \\ \text { Character read aloud } & \text { 母 } & \text { 来 } & \text { 亲 } & \text { 子 } & \text { 的 } & \text { 自 } & \text { 未 } \\ & & & & & & & \\ \text { Character shown } & \text { 水 } & \text { 色 } & \text { 旱 } & \text { 钓 } & \text { 池 } & \text { 豹 } & \text { 痛 } \\ \text { Character read aloud } & \text { 未 } & \text { 爸 } & \text { 早 } & \text { 的 } & \text { 地 } & \text { 钩 } & \text { 俑 }\end{array}$

The oral reading test showed that the patient often read one character as another one with a similar shape but different meaning and pronunciation.

Figure $2 \mathrm{MRI}$ of the brain
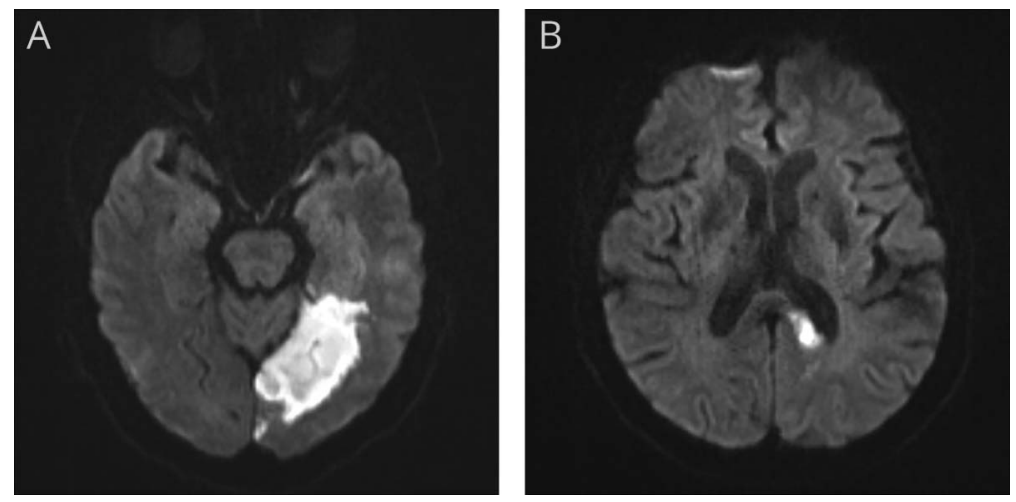

Brain MRI showed acute infarction involving the left occipital lobe, medial temporal lobe (A), and splenium of corpus callosum (B).

A 64-year-old literate Chinese man presented with sudden onset of difficulty reading. Examination revealed right homonymous hemianopsia and pure alexia. The oral reading test showed that he often read one character as another one with a similar shape but different meaning and pronunciation (figure 1). Brain MRI showed acute infarction involving the left occipital lobe, medial temporal lobe, and splenium of corpus callosum (figure 2). Pure alexia is a clinical disconnection syndrome that was first described in a patient with a similar infarction by Dejerine in $1892 .{ }^{1}$ Shape-similar errors may be a phenomenon characteristic of Chinese pure alexia.

*These authors contributed equally to this work.

From the Department of Neurology, Huashan Hospital, Fudan University, Shanghai, China.

Go to Neurology.org/N for full disclosures. Funding information and disclosures deemed relevant by the authors, if any, are provided at the end of the article. 


\section{Author contributions}

S.-L. Yang: collection and interpretation of data, manuscript drafting. X. Han: collection and interpretation of data. Q. Dong: supervision, critical revision of manuscript.

\section{Study funding}

No targeted funding reported.

\section{Disclosure}

The authors report no disclosures relevant to the manuscript. Go to Neurology.org/N for full disclosures.

\section{Reference}

1. Déjerine J. Contribution à l'étude anatomopathologique et clinique des différents variétés de cécité verbale[J] [in French]. Mémoires de la Société de Biologie 1892;4: $61-90$.

\section{Subspecialty Alerts by E-mail!}

Customize your online journal experience by signing up for e-mail alerts related to your subspecialty or area of interest. Access this free service by clicking on the "My Alerts" link on the home page. An extensive list of subspecialties, methods, and study design choices will be available for you to choose from-allowing you priority alerts to cutting-edge research in your field!

\section{Neurology ${ }^{\circledast}$ Online CME Program}

Earn CME while reading Neurology. This program is available only to online Neurology subscribers. Read the articles marked CME, go to Neurology.org, and click on CME. This will provide all of the information necessary to get started. The American Academy of Neurology (AAN) is accredited by the Accreditation Council for Continuing Medical Education (ACCME) to sponsor continuing medical education for physicians. Neurology is planned and produced in accordance with the ACCME Essentials. For more information, contact AAN Member Services at 800-879-1960.

\section{Visit the Neurology ${ }^{\circledR}$ Resident \& Fellow Website}

Click on Residents \& Fellows tab at Neurology.org.

Now offering:

- Neurology ${ }^{\circledR}$ Resident \& Fellow Editorial team information

- "Search by subcategory" option

- E-pearl of the Week

- RSS Feeds

- Direct links to Continuum ${ }^{\circledR}$, Career Planning, and AAN Resident \& Fellow pages

- Recently published Resident \& Fellow articles

- Podcast descriptions

f Find Neurology ${ }^{\circledR}$ Residents \& Fellows Section on Facebook: http://tinyurl.com/o8ahsys

Follow Neurology ${ }^{\circledR}$ on Twitter: http://twitter.com/GreenJournal 


\title{
Neurology
}

\author{
Shape-similar errors in Chinese pure alexia \\ Shi-Lin Yang, Xiang Han and Qiang Dong \\ Neurology 2019;92;388-389 \\ DOI 10.1212/WNL.0000000000006964
}

This information is current as of February 18, 2019

Updated Information \&
Services

References

Subspecialty Collections

Permissions \& Licensing

Reprints including high resolution figures, can be found at: http://n.neurology.org/content/92/8/388.full

This article cites 1 articles, 0 of which you can access for free at: http://n.neurology.org/content/92/8/388.full\#ref-list-1

This article, along with others on similar topics, appears in the following collection(s):

Assessment of cognitive disorders/dementia

http://n.neurology.org/cgi/collection/assessment_of_cognitive_disorder s_dementia

Infarction

http://n.neurology.org/cgi/collection/infarction

Visual processing

http://n.neurology.org/cgi/collection/visual_processing

Information about reproducing this article in parts (figures,tables) or in its entirety can be found online at:

http://www.neurology.org/about/about_the_journal\#permissions

Information about ordering reprints can be found online:

http://n.neurology.org/subscribers/advertise

Neurology ${ }^{\circledR}$ is the official journal of the American Academy of Neurology. Published continuously since 1951, it is now a weekly with 48 issues per year. Copyright @ 2019 American Academy of Neurology. All rights reserved. Print ISSN: 0028-3878. Online ISSN: 1526-632X.

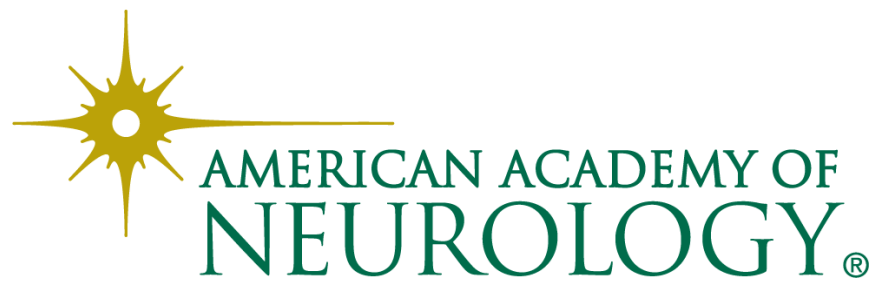

